\title{
PENGARUH PENGGUNAAN MEDIA KOMIK DALAM LAYANAN INFORMASI KARIR UNTUK MENINGKATKAN KEMATANGAN KARIR (Studi Kuasi Eksperimen Terhadap Peserta Didik Kelas VIII di SMP Labschool Jakarta)
}

\author{
Wening Cahyawulan ${ }^{1}$ \\ Dra. Wirda Hanim, M.Psi. ${ }^{2}$ \\ Herdi, M.Pd. ${ }^{3}$
}

\begin{abstract}
Abstrak
Penelitian ini bertujuan untuk meningkatkan kematangan karir peserta didik kelas VIII di SMP Labschool Jakarta melalui layanan informasi karir menggunakan media komik. Metode yang digunakan adalah kuasi eksperimen dengan pretest-posttest nonequivalent group design. Sampel dalam penelitian ini berjumlah 72 orang yang diambil dengan menggunakan teknik cluster sampling. Pengumpulan data dilakukan dengan menggunakan instrumen yang dikembangkan melalui konstruk Inventori Kematangan Karir yang dikemukakan Crites tahun 1973. Inventori kematangan karir terdiri dari dua pengukuran yaitu pengukuran terhadap sikap karir dan kompetensi karir. Teknik analisis data untuk memperoleh gambaran kematangan karir menggunakan statistik deskriptif berupa presentase dan teknik analisis data untuk uji hipotesis menggunakan t-test berupa independent sample t-test. Hasil uji hipotesis dilakukan dengan bantuan program SPSS 20.0 for windows yang menunjukkan bahwa pada sikap karir diperoleh Sig =0,000 dan pada kompetensi karir diperoleh Sig =0,000, hasil tersebut menunjukkan bahwa pada sikap karir maupun kompetensi karir diperoleh Sig < 0,05. Oleh sebab itu, diperoleh kesimpulan bahwa peningkatan kematangan karir peserta didik yang mendapatkan layanan informasi karir menggunakan media komik lebih tinggi dibandingkan peningkatan kematangan karir peserta didik yang tidak mendapatkan layanan informasi karir menggunakan media komik, baik pada sikap karir maupun kompetensi karir.
\end{abstract}

Kata Kunci: kematangan karir, inventori kematangan karir, layanan informasi karir,

\section{Pendahuluan}

Sejak tahun ajaran 2013/2014, pemerintah mulai menerapkan kurikulum 2013 di sekolah yang ditunjuk. Berlakunya kurikulum 2013 mengamanatkan adanya peminatan peserta didik yang merupakan suatu proses pengambilan pilihan dan keputusan oleh peserta didik dalam bidang keahlian yang didasarkan atas pemahaman potensi diri dan peluang yang ada. Oleh sebab itu, pelayanan bimbingan dan konseling berkaitan langsung dalam membantu kesesuaian peminatan bagi peserta didik. Terlebih pada kurikulum 2013, peserta didik akan menempati peminatan di kelas X. Sehingga, guru bimbingan dan konseling atau guru BK dituntut untuk mampu

\footnotetext{
Mahasiswa Jurusan Bimbingan dan Konseling FIP UNJ, wening.cahyawulan@gmail.com

2 Dosen Bimbingan dan Konseling FIP UNJ, wirdahanim10@gmail.com

3 Dosen Bimbingan dan Konseling FIP UNJ, herdiunj5@gmail.com
} 
memberikan informasi yang cukup lengkap terkait peminatan bagi peserta didik.

Hasil wawancara dan angket yang dilakukan di Sekolah Menengah Pertama Labschool Jakarta menunjukkan bahwa peserta didik masih belum mampu memilih peminatan serta karir yang sesuai untuk dirinya. Padahal jika dikaji secara teoritik, peserta didik yang berada pada tingkat Sekolah Menengah Pertama atau SMP merupakan individu yang berada pada tahap eksplorasi teori perkembangan karir Super (Sharf, 1992:124). Tahap eksplorasi merupakan tahap ketika individu berusaha untuk memahami dirinya dan menemukan posisinya dalam dunia kerja sehingga tercapai kematangan karir. Super mengungkapkan bahwa kematangan karir menunjuk pada keberhasilan seseorang menyelesaikan tugas-tugas perkembangan karir yang khas (Winkel \& Hastuti, 2006: 633). Oleh sebab itu, layanan informasi karir merupakan suatu layanan esensial yang dibutuhkan oleh peserta didik.

Layanan informasi karir yang dilakukan merupakan suatu bentuk komunikasi guru BK dengan peserta didik. Suatu komunikasi akan efektif jika didukung dengan media yang menarik. Peserta didik SMP merupakan individu yang berada pada tahap perkembangan remaja memiliki karakteristik menyukai media dengan unsur visual (American College of Pediatricians, 2013: 1). Salah satu media visual yang populer di SMP Labschool Jakarta adalah komik. Komik populer di SMP Labschool Jakarta, karena SMP Labschool Jakarta memiliki satu ekstra-kurikuler khusus bagi peserta didik untuk membuat komik.

Media komik memiliki keunggulan jika digunakan dalam layanan informasi karir karena mampu menyajikan suatu cerita dengan dikemas unsur visual yang mampu memudahkan peserta didik memahami informasi dalam kegiatan pembelajaran (Stafford, 2011: 55). Oleh sebab itu, penggunaan media komik dalam layanan informasi karir menjadi isu menarik bagi peneliti untuk meningkatkan kematangan karir peserta didik kelas VIII di SMP Labschool Jakarta.

\section{Kajian Teori \\ Kematangan Karir}

Menurut Tolbert, karir merupakan sekuensi oku- pasi-okupasi dimana seseorang ikut serta di dalamnya, beberapa orang mungkin tetap dalam okupasi yang sama sepanjang tahap-tahap kehidupannya, sedang yang lainnya mungkin memiliki rangkaian okupasi-okupasi yang begitu berbeda (Manrihu, 1992: 31). Sementara definisi karir yang populer, adalah definisi karir yang diungkapkan Super bahwa karir merupakan jalannya peristiwa-peristiwa kehidupan, sekuensi okupasi-okupasi dan perananperanan kehidupan lainnya yang keseluruhannya menyatakan tanggung jawab seseorang kepada pekerjaan dalam keseluruhan pola perkembangan dirinya (Marinhu, 1992: 31). Oleh sebab itu, karir dapat didefisinikan sebagai rangkaian okupasi, pekerjaan, dan jabatan selama kehidupan individu yang dipengaruhi psikologis, sosiologis, pendidikan, fisik, ekonomi, dan faktor-faktor lainnya.

Konsep kematangan karir diungkapkan oleh Super yang didefinisikan sebagai keberhasilan individu menyelesaikan tugas-tugas perkembangan karir yang khas bagi tahap tertentu (Winkel \& Hastuti, 2006: 633). Sementara, Crites mengungkapkan bahwa kematangan karir merupakan pusat perkembangan pendekatan untuk memahami perilaku karir dan melibatkan sebuah asesmen pada individu pada proses karir dalam hubungannya dengan tugas perkembangan karir yang relevan (Wendy Patton \& Peter A. Creed, 2001: 336). Pengukuran kematangan karir yang diungkapkan oleh Crites terbagi menjadi dua dimensi, yaitu dimensi afektif (sikap karir) dan kognitif (kompetensi karir). Sikap karir terdiri dari ketegasan, keterlibatan, kebebasan, orientasi, dan kompromi individu terhadap karir, sementara itu kompetensi kematangan karir terdiri dari penilaian diri, informasi karir, langkah-langkah mencapai tujuan, perencanaan, dan langkah menyelesaikan masalah. Berdasarkan hasil penelitian-penelitian sebelumnya, tampak bahwa kematangan karir dipengaruhi oleh gender, status ekonomi-sosial, usia, dan level pendidikan (Schmitt-Rodermund \& Silbereisen ,2008: 17).

\section{Layanan Informasi Karir}

Layanan informasi karir dilakukan oleh seorang guru BK untuk menjawab kebutuhan informasi dan tujuan karir kliennya (Yusuf, 2009: 21). Layanan informasi karir merupakan salah satu layanan bim- 
bingan yang menjadi bagian dari bidang bimbingan karir. Layanan informasi karir akan membantu peserta didik mengambil keputusan terhadap alternatif-alternatif karirnya di masa depan. Layanan informasi diberikan dalam strategi bimbingan klasikal, Damayati mengungkapkan bahwa bimbingan klasikal merupakan bantuan yang diberikan di dalam kelas berupa kegiatan yang kemudian dibahas secara terbuka dan bebas oleh semua peserta yang ada di dalam kelas tersebut untuk mendapatkan pengalaman dan pengetahuan. Layanan informasi karir sangat penting dilakukan pada tingkat SMP, hal ini dikarenakan kurikulum 2013 menekankan pada peminatan peserta didik di kelas X. Oleh sebab itu layanan bimbingan informasi karir yang diberikan pada tingkat SMP akan membantu peserta didik menentukan dengan tepat peminatan bagi dirinya ketika berada di SMA nantinya.

\section{Media Komik}

Collins mendefinisikan komik sebagai buku cerita seperti majalah yang ceritanya berkembang melalui panel-panel bergambar yang disusun secara berurutan sebagai alur cerita dan dialog yang berbentuk bubbles (Collins \& O'Brien, 2011: 84). Pada komik dikenal adanya panel-panel yang menjadi ciri khasnya (Stafford, 2011, 54). Selain itu, terdapat tiga unsur penting dalam komik yaitu speech bubbles, thought ballon, dan sound effect (Stafford, 2011: 57-59). Bahan bacaan komik dirasa menarik untuk dikonsumsi oleh anak-anak dan remaja karena sifatnya yang mudah dicerna dan lucu. Setiap orang bisa menikmatinya tanpa harus terlalu berpikir serius. Komik sesungguhnya lebih dari sekadar cerita bergambar yang ringan dan menghibur.

\section{Metode Penelitian}

Penelitan ini bertujuan untuk mengetahui pengaruh layanan informasi karir dengan menggunakan media komik dalam meningkatkan kematangan karir peserta didik kelas VIII di SMP Labschool Jakarta. Penelitian ini dilakukan di SMP Labschool Jakarta, sejak bulan Januari hingga bulan Mei 2014. Penelitian ini menggunakan pendekatan kuantitatif dengan metode kuasi eksperimen pretest-posttest nonequivalent group design. Oleh sebab itu, penelitian ini akan melibatkan kelompok eksperimen se- bagai kelompok yang akan mendapatkan perlakuan dan kelompok kontrol yang tidak mendapatkan perlakuan. Kedua kelompok akan mendapatkan pretest dan posttest yang bertujuan untuk mengetahui pengaruh variabel dependen $(\mathrm{X})$ yang tercermin dalam perbedaan variabel dependen khususnya $\mathrm{O} 2$ dan $\mathrm{O} 4$.

Penelitian dilakukan sebanyak enam kali pertemuan dengan dua kali pertemuan untuk tes dan empat kali pertemuan untuk pelaksanaan eksperimen. Selama pelaksanaan eksperimen peneliti menggunakan media komik yang telah dilakukan pengujian kualitas oleh tiga orang ahli konten dan tiga orang ahli media. Populasi dalam penelitian ini adalah seluruh peserta didik kelas VIII di SMP Labschool Jakarta yang berjumlah 240 orang. Sementara itu, teknik sampling yang digunakan dalam penelitian ini adalah cluster sampling dengan sampel berjumlah 72 orang, yaitu 36 orang peserta didik pada kelompok eksperimen dan 36 orang peserta didik pada kelompok kontrol.

Pada penelitian ini, pengukuran kematangan karir dilakukan dengan menggunakan instrumen yang dikembangkan dari konstruk Inventori Kematangan Karir oleh Crites pada tahun 1973. Inventori Kematangan Karir terdiri dari dua dimensi, yaitu dimensi afektif yang mengukur sikap karir dan dimensi kognitif yang mengukur kompetensi karir.

Kualitas skor peningkatan kematangan karir pada sampel penelitian diketahui melalui pengujian gain ternormalisasi menggunakan rumus sebagai berikut (Bao, 2004: 1):

Gain ternormalisasi $(\mathrm{g})=\frac{\text { skor } \text { posttest }- \text { skor } \text { pretest }}{\text { skor ideal }- \text { skor } \text { pretest }}$

Pengaruh eksperimen terhadap sampel penelitian diketahui melalui pengolahan data dan analisis data menggunakan uji t-tes yang secara operasional dilakukan dengan independent sample t-test menggunakan rumus sebagai berikut (Freund \& Wilson, 2003: 192):

$$
t=\frac{\bar{y}_{1}-\bar{y}_{2}}{\sqrt{s_{p}^{2}\left(\frac{1}{n_{1}}+\frac{1}{n_{2}}\right)}}
$$


Keterangan:

$$
\begin{aligned}
& \bar{y}_{1}: \text { mean kelompok eksperimen } \\
& \bar{y}_{2}: \text { mean kelompok kontrol } \\
& n_{1}: \text { jumlah subjek pada kelompok eksperimen } \\
& n_{2}: \text { jumlah subjek pada kelompok kontrol } \\
& s_{p}^{2}: \text { pooled variance }: \frac{S S_{1}+S S_{2}}{n_{1}+n_{2}+2} \\
& \mathrm{SS}_{1}:\left(n_{1}-1\right) s_{1}^{2} \\
& \mathrm{SS}_{2}:\left(n_{2}-1\right) s_{2}^{2} \\
& s_{1}^{2}: \text { varians kelompok eksperimen } \\
& s_{2}^{2}: \text { varians kelompok kontrol }
\end{aligned}
$$

\section{Hasil dan Pembahasan \\ Hasil Penelitian}

Berdasarkan hasil pengolahan data, maka deskripsi data pengukuran kematangan karir dibagi menjadi dua yaitu sikap karir dan kompetensi karir. Pada hasil pretest sikap karir kelompok eksperimen sebanyak 13,89\% berada pada kategori sedang, 69,44\% berada pada kategori tinggi, dan $16,67 \%$ berada pada kategori sangat tinggi. Sementara itu, hasil pretest kompetensi karir menunjukkan bahwa sebanyak $8,33 \%$ berada pada kategori rendah, $11,11 \%$ berada pada kategori sedang, $47,22 \%$ berada pada kategori tinggi, dan $33,34 \%$ berada pada kategori sangat tinggi.

Hasil pretest sikap karir kelompok kontrol menunjukkan bahwa sebanyak 2,78\% berada pada kategori sedang, $77,78 \%$ berada pada kategori tinggi, dan $19,44 \%$ berada pada kategori sangat tinggi. Sementara itu, hasil pretest kompetensi karir menunjukkan bahwa sebanyak $2,78 \%$ berada pada kategori rendah, $22,22 \%$ berada pada kategori sedang, $50 \%$ berada pada kategori tinggi, dan $25 \%$ berada pada kategori sangat tinggi.

Selanjutnya, setelah pelaksanaan eksperimen maka dilakukan posttest. Hasil posttest sikap karir kelompok eksperimen menunjukkan bahwa sebanyak $22,22 \%$ berada pada kategori tinggi dan $28 \%$ berada pada kategori sangat tinggi. Sementara, hasil posttest kompetensi karir menujukkan bahwa sebanyak $36,11 \%$ berada pada kategori tinggi dan $63,89 \%$ berada pada kategori sangat tinggi.

Hasil posttest sikap karir kelompok kontrol menunjukkan bahwa sebanya $83,33 \%$ berada pa- da kategori tinggi dan $16,67 \%$ berada pada kategori sangat tinggi. Sementara itu, hasil posttest kompetensi karir kelompok kontrol menunjukka bahwa sebanyak 2,78\% berada pada kategori sangat rendah, $13,89 \%$ berada pada kategori rendah, $38,89 \%$ berada pada kategori sedang, $38,89 \%$ berada pada kategori tinggi, dan 5,55\% berada pada kategori sangat tinggi.

Selanjutnya, gambaran kematangan karir pada sikap karir dan kompetensi karir dapat dilihat melalui grafik berikut ini:

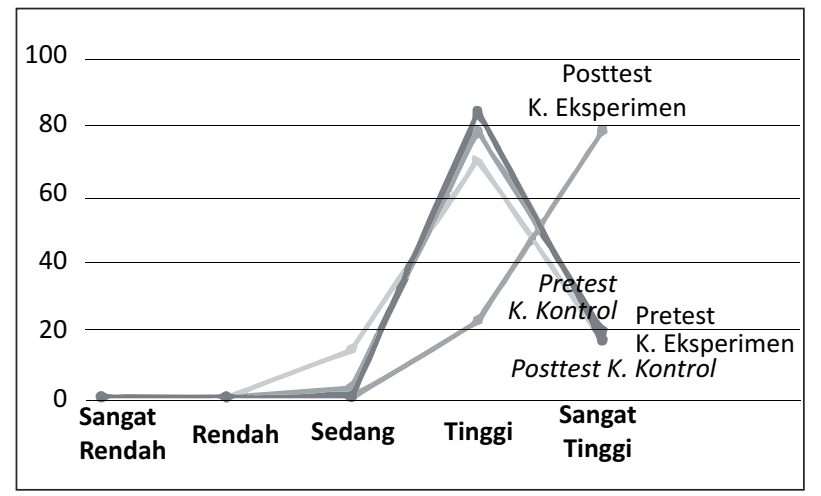

Grafik 1. Gambaran Kematangan Karir pada Sikap Karir

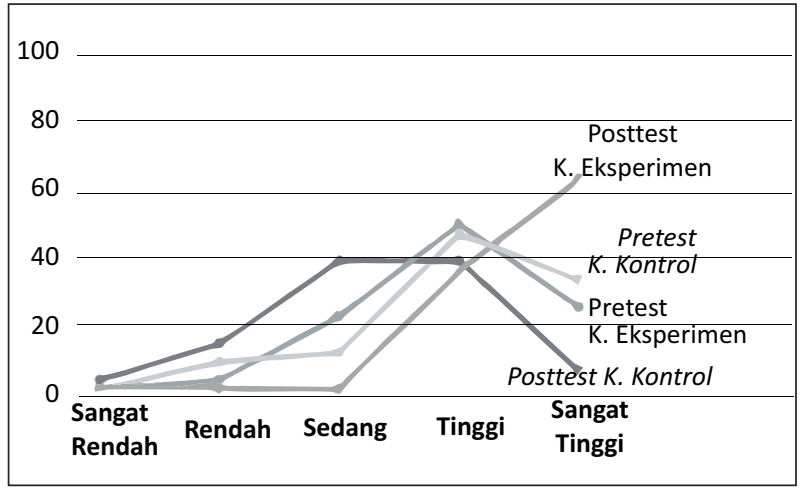

Grafik 2. Gambaran Kemantangan Karir pada Kompetensi Karir

Selanjutnya, dilakukan perhitungan gain ternormalisasi untuk mengetahui ada atau tidaknya perubahan ke tingkat yang lebih baik atau tidak bahkan tetap pada kematangan karir peserta didik melalui perbandingan skor kematangan karir ketika sebelum dan sesudah pelaksanaan eksperimen. Hasil perhitungan rata-rata gain ternormalisasi adalah sebagaimana terlihat pada Tabel 1 .

Hasil tersebut menunjukkan bahwa rata-rata 
skor gain ternormalisasi kematangan karir kelompok eksperimen pada sikap karir sebesar 0,354 artinya signifikansi berada pada kategori sedang, sementara pada kompetensi karir sebesar 0,261 artinya signifikansi berada pada kategori rendah. Sementara skor gain ternormalisasi kematangan karir kelompok kontrol pada sikap karir sebesar 0,02 artinya signifikansi berada pada kategori rendah, serta pada kompetensi karir sebesar -0,59 signifikansi berada pada kategori rendah bahkan menurun karena ditandai dengan tanda minus.

\section{Tabel 1. Rata-rata Skor Gain Ternormalisasi Kema-} tangan Karir

\begin{tabular}{|c|c|c|}
\hline & Kelompok Eksperimen & Kelompok Kontrol \\
\hline Sikap Karir & 0,354 & 0,02 \\
\hline Kompetensi Karir & 0,261 & $-0,59$ \\
\hline
\end{tabular}

Selanjutnya, dilakukan uji hipotesis satu ekor pada taraf kepercayaan 5\%. Berdasarkan hasil pengujian hipotesis menggunakan independent sample t-test dengan menggunakan bantuan software SPSS 20.0 for windows menunjukkan bahwa nilai signifikansi pada sikap karir dan kompetensi karir adalah 0,000. Hal tersebut menunjukkan bahwa pada sikap karir Sig $<0,05$ dan pada kompetensi karir Sig $<0,05$. Sehingga, dapat disimpulkan bahwa peningkatan kematangan karir peserta didik yang mendapatkan layanan informasi dengan menggunakan media komik lebih tinggi dibandingkan peningkatan kematangan karir peserta didik yang tidak mendapatkan layanan informasi karir menggunakan media komik.

\section{Pembahasan}

Berdasarkan hasil pengujian hipotesis, maka disimpulkan bahwa peningkatan kematangan karir peserta didik yang mendapatkan layanan informasi karir menggunakan media komik lebih tinggi dibandingkan peningkatan kematangan karir peserta didik yang tidak mendapatkan layanan informasi karir menggunakan media komik. Hasil pengujian hipotesis tersebut menunjukkan bahwa media komik yang digunakan dalam layanan informasi karir telah efektif. Hal ini dikarenakan media komik merupakan salah satu media yang mengandung unsur visual sehingga mendukung ketertarikan sampel penelitian yang merupakan individu pada tahap perkembangan remaja dengan karakteristik menyukai media yang mengandung unsur visual (American College of Pediatricians, 2013: 1). Selain itu, media komik efektif karena sebelum dilakukan eksperimen kepada sampel penelitian, media komik telah mendapatkan pengujian kualitas media komik oleh tiga orang ahli konten dan tiga orang ahli media. Hasil pengujian kualitas media komik mendapatkan hasil bahwa media komik sangat layak digunakan pada peserta didik tingkat SMP.

Secara khusus, sampel penelitian merupakan peserta didik di SMP Labschool Jakarta yang memiliki kegiatan ekstrakurikuler membuat komik sehingga popularitas media komik di SMP Lab school Jakarta tergolong tinggi dibandingkan dengan sekolah lainnya. Bahan bacaan komik memang dirasa menarik untuk dikonsumsi oleh anak-anak dan remaja karena sifatnya yang mudah dicerna dan lucu. Setiap orang bisa menikmatinya tanpa harus terlalu berpikir serius. Komik sesungguhnya lebih dari sekadar cerita bergambar yang ringan dan menghibur. Komik adalah suatu bentuk media komunikasi visual yang mempunyai kekuatan untuk menyampaikan informasi secara populer dan mudah dimengerti, termasuk salah satunya adalah informasi karir. Hal tersebut membuat komik tetap populer dikalangan remaja dan anak-anak bahkan di era modern seperti saat ini.

SMP Labschool Jakarta merupakan salah satu SMP favorit di Jakarta sehingga peserta didik yang bersekolah di SMP Labschool Jakarta merupakan individu pilihan yang berlatar belakang sosial, ekonomi, dan pendidikan orangtua yang tinggi. Hal tersebut mempengaruhi peserta didik dalam memilih karir di masa depan, sehingga kebutuhan peserta didik terhadap layanan informasi karir untuk mengetahui karir yang cocok baginya cenderung tinggi. Sementara itu, hal sebaliknya justru tampak dari guru BK di SMP Labschool Jakarta yang belum memberikan layanan informasi karir dengan media yang tepat bagi peserta didik sehingga belum mampu menjawab kebutuhan layanan informasi karir bagi peserta didik. Oleh sebab itu, hasil penelitian menunjukkan bahwa layanan informasi karir dengan menggunakan media komik berhasil disambut baik oleh peserta didik karena dianggap mampu menjawab kebutuhan peserta didik. Hal-hal tersebut diatas dapat dinyatakan sebagai dukungan terhadap 
keberhasilan layanan informasi karir dengan menggunakan media komik dalam meningkatkan kematangan karir peserta didik.

Pada penelitian ini, peneliti tidak mengontrol faktor lain yang dapat mempengaruhi kematangan karir peserta didik, terutama faktor lingkungan. Oleh sebab itu, layaknya penelitian eksperimen pada umumnya, desain penelitian eksperimen ini pun memiliki ancaman (threat). Ancaman tersebut adalah history yaitu peristiwa yang terjadi selama waktu pelaksanaan eksperimen yang mungkin mempengaruhi observasi (Heppner et al, 2008: 93). Kejadian-kejadian tersebut mungkin terjadi ketika di sekolah atau di rumah (Heppner et al, 2008: 93). Sehingga, disadari bahwa hasil penelitian yang menunjukkan bahwa peningkatan kematangan karir kelompok eksperimen secara signifikan lebih tinggi dibandingkan kelompok kontrol, tidak dapat dikatakan sepenuhnya karena pengaruh penggunaan media komik dalam layanan informasi karir. Hal tersebut karena adanya kemungkinan peristiwa-peristiwa yang terjadi selama pelaksanaan eksperimen yang dapat mempengaruhi kematangan karir peserta didik.

Selain itu, salah satu kelemahan dalam desain yang digunakan dalam penelitian ini adalah bahwa sangat mungkin kedua kelompok saling mempengaruhi satu sama lain, baik kelompok eksperimen kepada kelompok kontrol atau sebaliknya. Hal tersebut mungkin terjadi dalam penelitian ini, karena baik kelompok eksperimen atau kelompok kontrol, keduanya merupakan peserta didik kelas VIII yang sama-sama menempuh pendidikan di SMP Labschool Jakarta. Sehingga, interaksi antar kedua kelompok mungkin terjadi. Hal-hal tersebut dapat mempengaruhi kematangan karir peserta didik.

\section{Simpulan dan Saran}

Berdasarkan hasil pengujian hipotesis komparatif pada penelitian ini, diperoleh hasil bahwa layanan informasi karir menggunakan media komik berpengaruh secara signifikan terhadap peningkatan kematangan karir peserta didik, baik pada sikap karir maupun pada kompetensi karir. Selanjutnya, pada perhitungan gain ternormalisasi diperoleh kesimpulan bahwa layanan informasi karir menggunakan media komik berpengaruh sedang terhadap peningkatan sikap karir dan berpengaruh rendah terhadap peningkatan kompetensi karir.

Berdasarkan hasil penelitian, maka disarankan pada guru BK SMP Labschool Jakarta untuk dapat menggunakan media komik yang dikembangkan dalam penelitian ini. Selain digunakan sebagai media dalam bimbingan klasikal, media komik juga dapat dimanfaatkan untuk kegiatan bimbingan kelompok, konseling kelompok, ataupun konseling individual. Selain itu, diharapkan guru BK SMP Labschool Jakarta mampu memelihara keberhasilan layanan informasi menggunakan media komik pada peserta didik yang merupakan kelompok eksperimen pada penelitian ini. Hal tersebut dikarenakan peserta didik masih membutuhkan dukungan yang terus berkelanjutan dari pihak sekolah agar peserta didik berhasil mencapai karir yang sesuai dengan dirinya.

Guru BK SMP Labschool Jakarta sebaiknya juga melakukan beberapa tes psikologis untuk membantu peserta didik mengenali dirinya, seperti tes bakat, tes minat, dan tes kepribadian. Hal ini akan mendukung peserta didik mencapai kematangan karir yang lebih optimal. Sementara, bagi guru BK yang akan menggunakan media komik di luar SMP Labschool Jakarta, hendaknya melakukan revisi terlebih dahulu pada media komik sesuai dengan kebutuhan dan karakteristik di sekolah yang bersangkutan.

Bagi peneliti selanjutnya yang akan melakukan penelitian mengenai kematangan karir dapat melakukan penelitian terhadap fakor lain yang mempengaruhi kematangan karir seperti usia, jenis kelamin, dan sebagainya. Sementara peneliti selanjutnya yang akan melakukan penelitian dengan menggunakan media komik diharapkan mengembangkan media komik dengan konten yang lebih komprehensif dan desain yang lebih menarik. 


\section{Daftar Pustaka}

American College of Pediatricians. (2013). The Media, Children, and Adolescents. Retrieved from http:// www.acpeds.org/wp-content/uploads/10.21.13_TheMedia-children-and-adolescents-final.pdf.

Bao, Lei. (2006). Theoritical comparisons of average normalized gain calculations. Physics Education Research, 74 (10), 917-922. Retrieved from http://www. physics.ohio-state.edu/ lbao/Papers/AJP_2006-10917-g-factor1.pdf.

Collins, John W., \& Nancy Patricia O'Brien. (2011). The Greenwood Dictionary of Education. California: Greenwood.

Damayati, Nidya. (2012). Buku Pintar Panduan Bimbingan Konseling. Yogyakarta: Araska.

Freund, Rudolf J., \& William J. Wilson. (2003). Statistical Methods. California: Elsevier Science.

Heppner, P. Paul et al. (2008). Research Design in Counseling. Belmont: Thomson Higher Education.

Manrihu, Mohammad Thayeb. (1992). Pengantar Bimbingan dan Konseling Karier. Jakarta: Bumi Aksara.
Patton, Wendy, \& Peter A. Creed. (2001). Developmental Issues in Career Maturity and Career Decision Status. The Career Development Quarterly. 4 (4), 336-351.

Schmitt-Rodermund, Eva., \& Rainer K. Silbereisen. (1998). Career Maturity Determinants: Individual Development, Social Context, and Historical Time. The Career Development Quarterly, 47 (1), 16-31.

Sharf, Richard S. (1992). Appying Career Development Theory to Counseling. California: Brooks/Cole Publishing.

Stafford, Tim. (2011). Teaching Visual Literacy in Primary Classroom, Comic, Film, Television and Picture Narratives. New York: Routledge.

Winkel, W.S., \& M.M. Sri Hastuti. (2006). Bimbingan dan Konseling di Institusi Pendidikan. Yogyakarta: Media Abadi.

Yusuf, Syamsu. (2009). Landasan Bimbingan dan Konseling. Bandung: Remaja Rosadakarya. 